\title{
Shark atTacks on the Transkei coAst of South Africa: A CASE REPORT
}

Author:

Banwari L. Meel ${ }^{1}$

\section{Affiliation:}

${ }^{1}$ Department of Forensic

Medicine, Walter Sisulu

University for Technology

and Science, South Africa

\section{Correspondence to:}

Banwari L. Meel

e-mail:

bmeel@wsu.ac.za

\section{Postal address:}

Private Bag X1, UNITRA

Mthatha 5117, South Africa

\section{Keywords:}

safety from shark attacks; surfing; animal

behaviour; Transkei coast;

South Africa

\section{Dates:}

Received: 11 Mar. 2009

Accepted: 30 Apr. 2009

Published: 07 July 2009

How to cite this article: Meel BL. Shark attacks on the Transkei coast of South Africa: A case report. Afr J Prm Health Care Fam Med. 2009;1(1), Art. \#48, 2 pages. DOI: $10.4102 /$ phcfm.vli1.48

This article is available at: http://www.phcfm.org

(c) 2009. The Authors. Licensee: OpenJournals Publishing. This work is licensed under the Creative Commons Attribution License.

\section{ABSTRACT}

Shark attacks are relatively uncommon, but can be fatal in nature. It is difficult to understand the behaviour and motivation of this predator.

In the summer of 1998 a 28-year-old male, who was an experienced, enthusiastic surfer, was attacked by a shark near Hole-in-the Wall on the Wild Coast in the Transkei region of South Africa. His right lower limb was severed, with profuse bleeding from the torn femoral artery. Sharp broken ends of the femur and torn muscles were noticed at autopsy. The viscera were extremely pale. The lungs, in addition to being pale, were shrunken and dry, and there was no fluid that oozed out upon squeezing the cut surface. The case history, physical findings, and medico-legal implications are discussed in this report. Preventive and safety measures related to shark attacks are suggested.

\section{INTRODUCTION}

More people are killed by lightning strikes, bee stings and snake bites every year than by shark attacks. Worldwide, the estimated incidence of shark attacks is between 50 and 100 annually. The majority occur in warm, murky water, less than five feet in depth, within 100 feet of the shore, around sunset or sunrise. ${ }^{1}$ South Africa has a 3500-km-long coastline, and the number of shark attacks along the coast is on the increase. Figures for the years 1998-2004 are the following: in the Western Cape there were 49 attacks, of which eight were fatal, and in the Eastern Cape there were 26 attacks, of which three were fatal. ${ }^{2}$

Shark attacks on humans result in considerable speculation as to how they occurred and the motivation of the animals. The victim, if alive, will recall certain phases of an incident, but rarely sighting the animal approaching. Understanding the approach behaviour of a shark can explain the bite pattern later manifested in the wound structures.

Victims of shark attacks usually sustain only minor injuries. In more serious cases, particularly if associated with major vascular injury, haemorrhage control and early resuscitation are of utmost importance during the initial management if these patients are to have a chance of surviving. ${ }^{4}$

The purpose of this case report is to highlight the problem of shark attacks, particularly ahead of the 2010 Soccer World Cup.

\section{Case history}

Mr M. was a 28-year-old white male who had been surfing near Hole-in-the-Wall, on the Eastern Cape coast, along with two of his friends. He was fiercely attacked by a shark, resulting in his right leg being severed at the hip (Figure 1). His body was discovered an hour later, along with the severed limb, floating on the water. The body was brought to the mortuary at Umtata General Hospital for an autopsy.

The deceased was very pale. On opening the chest and abdomen, the lungs and abdominal organs appeared pale and shrunken. There were no signs of waterlogging of the lungs. The right lower limb was severed at the hip. The femoral vessels were torn. The femur had a razor sharp cut. No teeth were found at autopsy and none were seen on X-ray. No body parts had been devoured by the animal.

\section{DISCUSSION}

Fatal traumatic deaths by shark bites are rare. However, when they do occur, they draw the attention of the media. The majority of shark bite injuries are not serious, but those that are serious represent a major threat to life. Generally shark bites are minor lacerations and puncture wounds, caused by so-called 'hitand-run' encounters. ${ }^{5}$

The Transkei is known for its spectacular coastline and beaches. Although there are shark nets in metropolitan areas such as Durban, the Wild Coast of the Transkei has no such protection. 400000 visitors are expected to visit South Africa for the 2010 Soccer World Cup, many of whom can be expected to engage in water sports in the sea. Therefore those enjoying the sea in this area are more vulnerable to shark attacks.

Mr M. was a victim of a 'hit-and-run' attack. Two other surfers were eyewitnesses to his attack. He was attacked suddenly and disappeared under the water. A video of a white shark biting a human being was used to analyse the approach behaviour of the animal, and its possible motivation, in connection with the actual bite pattern. ${ }^{3}$ The following interesting fact emerged from a shark video tape study: of the six victims whose legs were covered, two of them were bitten twice, while none of the bare legged victims was bitten a second time. ${ }^{3}$ Play behaviour as a bite motivation, particularly in the case of white sharks, has also been suggested. ${ }^{6}$

This case seems to be a definitive attack by a white shark that probably occurred during feeding time in the morning, and which unfortunately coincided with the time that Mr M. was surfing. In a typical case 


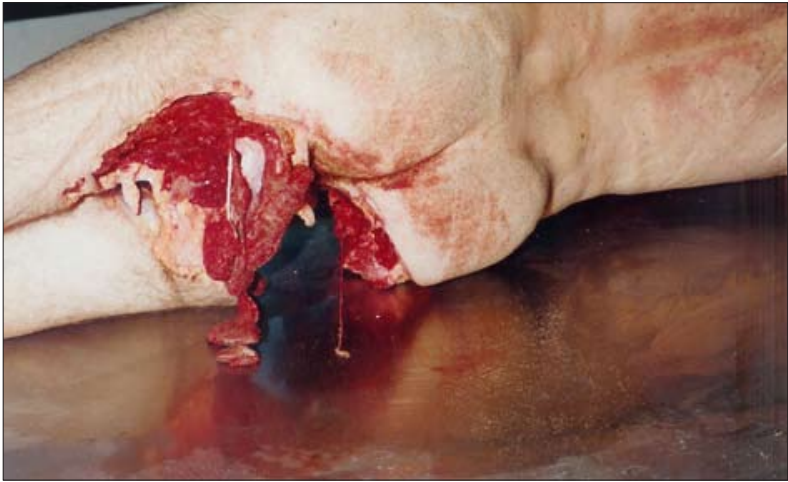

FIGURE 1

Severed limb aligned on autopsy table

of drowning the lungs are heavy, boggy and oedematous, but in $\mathrm{Mr} \mathrm{M}$. all these signs were absent. This is similar to a situation where a body is thrown into the water after being killed. All viscera were extremely pale, indicating that there was rapid loss of blood from the body. The majority of fatal shark attack victims can be saved if bleeding is arrested and the subject resuscitated. $\mathrm{Mr} \mathrm{M}$. was one of those who rapidly lost blood and succumbed to the injuries.

Davies and Campbell ${ }^{7}$ have classified shark bites by taking the site of arterial injury into account, and have used this as a prognostic indicator. Two victims in their series had grade 1 injuries, with proximal femoral arterial transections, and both had died within minutes of the initial attack. It appears that victims of injury exsanguinate so quickly that they are often moribund before reaching the beach. ${ }^{7}$ This happened in the case of $\mathrm{Mr} \mathrm{M}$ : there was no time for drowning, and therefore the lungs were dry.

Sharks tend to inflict large, irregular, clean-cut wounds (Figure 1). Large bites, such as the one of Mr M.'s thigh and buttock, often result in soft-tissue loss corresponding to the dimensions of the jaw. Sharks have several rows of sharp-pointed teeth with serrated edges, and often cause avulsion and de-gloving of soft tissue as the victim attempts to withdraw the limb from the mouth of the shark. Inexperienced pathologists may misinterpret these wounds as homicidal in nature, especially in the absence of reliable witnesses. Traumatic amputations are not infrequent, given the size and power of its jaws, and it is therefore not surprising that this animal is responsible for many fatal attacks. ${ }^{4}$

\section{Conclusion}

It is suggested that the Surf Lifesaving Association of South Africa should adequately equip itself to carry out effective first aid to shark attack victims, particularly victims with large vessel damage. The Transkei Wild Coast with its popular beaches is not protected with shark nets, and therefore they are not safe. With the 2010 Soccer World Cup taking place in the not too distant future, it would be prudent to train personnel in managing shark attack victims and to enlighten sports lovers about avoiding situations that may lead to such attacks.

\section{REFERENCES}

1. Guidera KJ, Ogden JA, Highhouse K, Pugh L, Beatty E. A case study of the injury and treatment: Shark attack. J Orthop Trauma. 1991;5(2):204-208.

2. Sharks. International Shark Attack file. Ichthyology, Florida Museum of Natural History, University of Florida [homepage on the Internet]. No date [cited 2007 April 28]. Available from: http://www.flmnh.ufl.edu/fish/sharks/ white/SAfrica.htm.

3. Ritter E, Levine M. Use of forensic analysis to better understand shark attack behavior. The Journal of Forensic Odoto-Stomatology. 2004;22(2):40-46.

4. Woolgar JD, Cliff G, Nair R, Hafez H, Robbs JV. Shark attack: Review of 86 consecutive cases. J Trauma. 2001; 50(5):887-891.

5. Maas T. Bluewater Hunting and Freediving. Ventura: BlueWater Freedivers; 1995. p. 25-48.

6. Compagno LJM. Sharks of the world. FAO Species Catalogue, Vol. 2. Rome: FAO; 2001. p.101.

7. Davies DH, Campbell GD. The aetiology and clinical pathology and treatment of shark attacks. J R Nav Med Serv. 1962;68:1-27. 